\section{Commentary: Vascularization and perfusion of engineered tissues}

\author{
Ming-Sing Si, MD
}

A remarkable milestone in medicine was the development of organ transplantation. ${ }^{1}$ The fascination of immediately reversing organ failure and illness with a surgical procedure still captures the attention of patients, care providers, and bystanders to this day. Although acute and chronic allograft rejection prevent solid-organ transplantation from being the silver bullet to disease, it still is the gold-standard treatment of end-stage organ disease. Nonetheless, because of the myriad of issues with allorecognition, immunosuppression, and donor organ shortage, alternatives to solid-organ transplantation are necessary for those who are not candidates for this treatment or who aren't fortunate enough to receive one.

One such alternative to tissue and organ transplantation is tissue engineering, a field that is at least a half-century old and is the topic of a timely review by Zhang and Radisic in this issue of the Journal. ${ }^{2}$ Some of the boldest proclamations in this field are to bioprint tissues 3-dimensionally in $\mathrm{situ}^{3}$ or to decellularize human or animal hearts and repopulate them with patient-derived cells. ${ }^{4}$ While these sophisticated methods have stimulated excitement, numerous follow-up studies, the expenditure of a significant amount of resources, and fantastical predictions of what these technologies are capable of, there is still a lack of a vascularized tissue-engineered construct that could be implanted and function just as an organ allograft.

Several major roadblocks have hindered the in vitro creation of tissue-engineered organs. The lack of a perfused, complete vascular network in tissue-engineered tissues and organs is a critical one and is highlighted in the review by Zhang and Radisic. ${ }^{2}$ From the perspective of the heart, it is well known that the amount of blood flow (oxygen and

\footnotetext{
From the Section of Pediatric Cardiovascular Surgery, Department of Cardiac Surgery, University of Michigan, Ann Arbor, Mich.

Disclosures: Author has nothing to disclose with regard to commercial support.

Received for publication Oct 27, 2019; revisions received Oct 27, 2019; accepted for publication Oct 28, 2019; available ahead of print Dec 4, 2019.

Address for reprints: Ming-Sing Si, MD, 11-735 C. S. Mott Children's Hospital SPC 4204, 1540 E. Hospital Dr, Ann Arbor, MI 48109-4204 (E-mail: mingsing@umich. edu).

J Thorac Cardiovasc Surg 2020;159:2008-9

$0022-5223 / \$ 36.00$

Copyright (c) 2019 by The American Association for Thoracic Surgery

https://doi.org/10.1016/j.jtcvs.2019.10.119
}

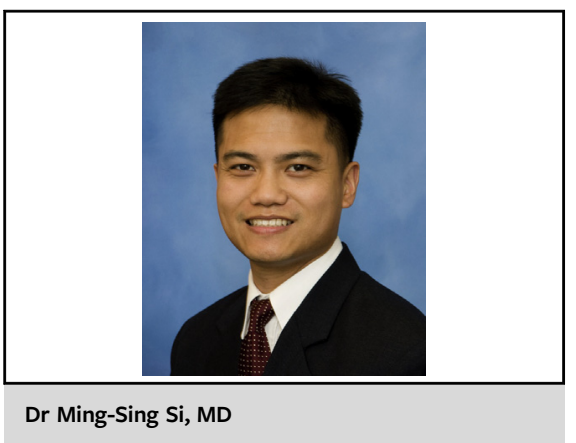

CENTRAL MESSAGE

No perfused vasculature $=$ no engineered organs and tissues.

nutrient delivery) is directly related to the mechanical work (cardiac output) and viability of the heart, ${ }^{5}$ and this principle relationship between blood flow and the function and viability of other organs and tissues universally applies. Thin sheets of cardiomyocytes are able to survive without vasculature as the oxygen is extracted directly from the environment and are being proposed as epicardiumapplied therapeutic devices. ${ }^{6}$ However, the direct contribution of these thin sheets to the overall mechanical work of the heart is negligible, considering that the amount of oxygen extracted (proportional to work output) by passive diffusion, which may be as much as 1000 times less than the amount that is delivered to the heart via blood perfusion of the coronary vessels, $80 \mathrm{~mL} / \mathrm{min} / 100 \mathrm{~g}$.

Thus, to create a substantial, thick, tissue-engineered heart construct, perfused vasculature must be included. The vasculature must be multiscalar and form a complete vascular network composed of an arterial inlet, venous outlet, and an intervening capillary network. Threedimensional bioprinting has the ability to create macrovasclature, but the creation of a microvascular network is still challenging. In decellularized organs, capillary networks are also incompletely rebuilt upon reseeding with endothelial cells.

Nonetheless, progress has been made in the past several decades in addressing this tissue vascularization and perfusion challenge, an obstacle that took evolution hundreds of millions of years to overcome. ${ }^{7}$ The vascularization problem is indeed the "Mars Mission of Bioengineering," as regarded by Zhang and Radisic. ${ }^{2}$ In fact, NASA has sponsored a vascularization tissue challenge (https://www.nasa.gov/ directorates/spacetech/centennial_challenges/vascular_tissue. $\mathrm{html}$ ) to stimulate the creation of vascularized thick tissues so that this technology could be used in treating astronauts 
on Mars, where they are distant from Earth-based medical care. Although NASA and other organizations supporting this award should be applauded for their recognition of this important obstacle, it is also equally surprising that the National Institutes of Health has not placed tissue vascularization as a specific, high priority. Determining how to vascularize and perfuse tissues and organs in vitro as well as accomplish rapid scale-up would likely help us understand how to induce native vascularization in vivo more efficiently and should help with the treatment of other diseases.

Although there are other challenges in making replacement organs in vitro, tissue vascularization remains the most critical and necessary one to solve. Gene-editing animals to create humanized organs to be used in xenotransplantation perhaps may result in a viable alternative to engineered tissues and organs, albeit with a host of other, including ethical considerations when applying to humans. In the interim, surgical organ replacement with allotransplantation remains the gold-standard treatment and underscores its fascination and value as the true gift of life.

\section{References}

1. Marino IR, Cirillo C. An abridged photographic history of organ transplantation. Exp Clin Transplant. 2014;12(suppl 1):11-6.

2. Zhang B, Radisic M. Organ-level vascularization: the Mars mission of bioengineering. J Thorac Cardiovasc Surg. 2020;159:2003-7.

3. Hong N, Yang GH, Lee J, Kim G. 3D bioprinting and its in vivo applications. Biomed Mater Res B Appl Biomater. 2018;106:444-59.

4. Guyette JP, Charest JM, Mills RW, Jank BJ, Moser PT, Gilpin SE, et al. Bioengineering human myocardium on native extracellular matrix. Circ Res. 2016;118: $56-72$.

5. Goodwill AG, Dick GM, Kiel AM, Tune JD. Regulation of coronary blood flow. Compr Physiol. 2017;7:321-82.

6. Ishigami M, Masumoto H, Ikuno T, Aoki T, Kawatou M, Minakata K, et al. Human iPS cell-derived cardiac tissue sheets for functional restoration of infarcted porcine hearts. PLoS One. 2018;13:e0201650.

7. Monahan-Earley R, Dvorak AM, Aird WC. Evolutionary origins of the blood vascular system and endothelium. J Thromb Haemost. 2013;11(suppl 1): 46-66. 